DOI: http://dx.doi.org/10.17651/ONOMAST.63.24

Onomastica LXIII, 2019

PL ISSN 0078-4648

\title{
DIALEKTOLOGIA W PRACACH NAUKOWYCH PROFESORA JÓZEFA BUBAKA
}

Obok onomastyki drugą uprawianą przez profesora Józefa Bubaka dziedziną językoznawstwa była dialektologia.

Celem artykułu jest ogólna charakterystyka dzieł dialektologicznych profesora Józefa Bubaka i zwrócenie uwagi na to, że znajomość gwar była uczonemu przydatna w jego interpretacjach onomastycznych.

Twórczość naukową w tym zakresie zapoczątkował profesor Bubak swą pracą magisterską „Gwary Koniakowa, Istebnej, Jaworzynki i Wisły”, napisaną pod kierunkiem W. Taszyckiego, obronioną w roku 1956, a opublikowaną dopiero w roku 1978 (Bubak, 1978).

Po tej młodzieńczej pracy, ukazującej dobre opanowanie aparatu badawczego, stanowiącej wartościowy przyczynek do wiedzy o gwarach Śląska Cieszyńskiego, nastąpiły dalsze badania na przemian onomastyczne i dialektologiczne. Tu zajmiemy się tylko tymi drugimi.

Na przełomie lat pięćdziesiątych i sześćdziesiątych ubiegłego wieku, pod kierunkiem profesorów Mieczysława Karasia i Alfreda Zaręby, wyruszyła grupa młodych dialektologów na badania terenowe na obszarze Orawy w obrębie państwa polskiego. Najbardziej doświadczonymi wśród nich byli niewątpliwie Józef Bubak, Roman Laskowski i Władysław Lubaś. Zespół ten znalazł w terenie dobrych informatorów gwarowych i dokonał nagrań tekstów, które po przeprowadzeniu odpowiednich sprawdzeń, dokonanych przez kierowników zespołu, ukazały się drukiem w roku 1964 jako „Orawskie teksty gwarowe z obszaru Polski” autorstwa Mieczysława Karasia i Alfreda Zaręby (Karaś, Zaręba, 1964).

Badania orawskie zachęciły młodego wówczas badacza, asystenta Józefa Bubaka, do kontynuacji tego typu poszukiwań naukowych na innych obszarach. Zaczął od Podhala. Miejscem badań stała się oddalona nieco od głównego szlaku komunikacyjnego wieś Ząb, w której bardzo dobrze zachowała się pierwotna gwara podhalańska. Badacz zarejestrował tam pokaźną liczbę tekstów, które wydał jako osobną książkę, liczącą 70 stron, zatytułowaną „Teksty gwarowe ze wsi Ząb w powiecie nowotarskim" (Bubak, 1966). Jest rzeczą zdumiewającą, że gwara podhalańska, wzbudzająca od dawna tyle zainteresowania ze względu na jej specjalny status w kulturze polskiej, nie miała przed Bubakiem dużego, w pełni naukowego zbioru tekstów gwarowych. Licznym, obfitym nawet, znakomitym $\mathrm{z}$ literackiego punktu widzenia tekstom, dokonanym przez wcześniejszych badaczy, brak było precyzji zapisu fonetycznego. Bubak wypełnił tę lukę dostarczając znakomitego materiału tak do dalszych badań gramatycznych, jak do wielkiego słownika gwary podhalańskiej, opracowywanego obecnie przez profesora Józefa Kąsia (Kąś, 2015-2019).

Przyjrzyjmy się wsi Ząb w roku 1962, wtedy gdy dwudziestokilkuletni Bubak przeprowadzał w niej badania. A oto co pisze autor we Wstępie do omawianego zbioru tekstów:

Ząb wraz z przysiółkami liczy około 2 tysiące mieszkańców. Głównym zajęciem mieszkańców jest rolnictwo i pasterstwo, tylko nieliczni pracują poza wsią w Zakopanem i w Nowym Targu. Obecnie dokonują się tam znaczne zmiany. Wiele młodzieży uczęszcza do szkół średnich w Zakopanem, a następnie studiuje na wyższych uczelniach, głównie w Krakowie (AGH i AM).

Rolnictwo stoi na niskim poziomie, metody uprawy roli prymitywne. Ze względu na górzyste położenie gruntów nie można stosować na szerszą skalę zmechanizowanych środków

This is an Open Access article available at: https://onomastica.ijp.pan.pl, https://rcin.org.pl

(C) Copyright by Instytut Języka Polskiego PAN, Kraków 2019.

Publisher: Institute of Polish Language, Polish Academy of Sciences

[Wydawca: Instytut Języka Polskiego Polskiej Akademii Nauk] 
uprawy roli, na nieurodzajnych glebach rodzi się głównie owies i ziemniaki. Wszystko to sprawiło, że samo rolnictwo nie mogło zapewnić bytu mieszkańcom wsi, dlatego drugim ważnym i tradycyjnym ich zajęciem obok rolnictwa jest pasterstwo. Kiedyś było ono może ważniejsze jak rolnictwo, obecnie jego rozwój jest zahamowany i ograniczany, kurczą się bowiem tereny wypasowe w Tatrach, a wypasy w Bieszczadach są mało popularne.

Od XVII w. Ząb należał do wsi góralskich, które miały najwięcej owiec na wypasie w Tatrach (do 3000 sztuk). Od XVII w. do czasów przed II wojną światową pasterstwo ciągle się rozwijało (por. Z. Hołub-Pacewiczowa, Osadnictwo pasterskie $i$ wędrówki w Tatrach i na Podtatrzu, Kraków 1931, s. 97, 226). Jak już zaznaczyłem, dziś pasterstwo powoli zanika i tylko część młodych ludzi jest przy nim zatrudniona, podczas gdy ze starszej generacji prawie wszyscy mężczyźni przez co najmniej kilka lat paśli na hali, a wielu z nich spędziło tam większą część życia. Właśnie pasterstwo wywarło największe piętno na życiu i kulturze wsi. Tematy związane z życiem pasterskim najczęściej przewijają się wśród niniejszych opowiadań.

Ząb, choć położony w bezpośrednim sąsiedztwie Zakopanego, nie ma jednak z nim dobrej komunikacji (stroma i gruntowa droga) [tak było w roku 1962!], do innych stacji kolejowych i przystanków autobusowych jest jeszcze trudniejszy dostęp. W związku z tym ruch letniskowy jest stosunkowo mały. Przynajmniej więc od tej strony gwara tej wsi nie była narażona na silniejszy wpływ języka literackiego, jak to się dzieje od kilkudziesięciu lat w innych wsiach podhalańskich. Obecnie jednak ta przeszkoda naturalna jest pokonywana przez radio, 7-klasową szkołę a ostatnio także, przez telewizję i polszczyzna literacka coraz łatwiej i częściej dostaje się do tutejszej gwary. Nie trzeba więc uzasadniać potrzeby zbierania, zapisywania czy nagrywania tekstów gwarowych.

Teksty niniejsze nagrałem na taśmę magnetofonową magnetofonem marki KB-100 produkcji NRD latem $1962 \mathrm{r}$. Wszystkie teksty wielokrotnie przesłuchałem, następnie przepisałem i włączyłem do niniejszego zbioru. Muszę zaznaczyć, że nim przystąpiłem do nagrywania i przepisywania tych tekstów $\mathrm{z}$ taśmy, miałem już za sobą pewien okres badań nad gwarą Zębu i dużo zebranego materiału. Ułatwiło mi to znakomicie pracę nad tekstami, gdyż byłem zorientowany w ważniejszych problemach tej gwary i dobrze z nią osłuchany.

Większość tekstów odsłuchiwałem i transkrybowałem na miejscu w Zębie, co pozwalało mi od razu wyjaśnić wszystkie wątpliwe problemy związane z nagraniami, u informatorów, których nagrywałem. Należy bowiem pamiętać że nagrania bezpośrednio na wsi dokonywane sa w prymitywnych warunkach w chłopskiej izbie, bez specjalnego pomieszczenia, które eliminowałoby hałas często przy dużej liczbie przysłuchujących się mieszkańców wsi, którzy w takich warunkach nie zawsze wykazują zrozumienie dla charakteru pracy. Dlatego też zdarza się, że niektóre słowa opowiadających ulegają zniekształceniu, ważne jest więc to, żeby dane nagranie na miejscu przesłuchać $i$ wszystkie wątpliwości wynikłe ze zniekształceń tekstu wyjaśnić.

Jeżeli idzie o reakcję mieszkańców Zębu na propozycję nagrania ich opowiadań na taśmę, były dość różnorodne od entuzjastycznych do bardzo powściągliwych. $\mathrm{Ci}$ ostatni, nieliczni zresztą, obawiali się, że ich opowiadanie będzie nadawane przez radio i w związku z tym nie chcieli opowiadać, trzeba było dopiero użyć wielu słów perswazji, żeby ich namówić do opowiadania. W większości wypadków jednak bardzo chętnie opowiadali, poświęcając na nagrywanie wiele czasu, a słuchanie własnego głosu z taśmy sprawiało im dużo satysfakcji, nawet radości. Nagrywania dokonywane przeze mnie były pierwszymi tego rodzaju na terenie Zębu. Inaczej wygląda ta sprawa w innych wsiach Podhala, np. w Bukowinie Tatrzańskiej, gdzie górale „zepsuci” częstymi wizytami Radia, Filmu i Telewizji bezinteresownie opowiadali niechętnie (Bubak, 1966, s. 5-6).

Wnet po wydaniu zbioru tekstów ze wsi Ząb wyruszył Józef Bubak na Spisz, gdzie w kilkunastu wsiach położonych na terenie Polski zarejestrował w latach 1967-1970 137 tekstów. Teksty te 
wydał w roku 1972 w liczącej 151 stron książce, zatytułowanej „Spiskie teksty gwarowe z obszaru Polski” (Bubak, 1972). Podobnie jak Podhale Spisz nie miał przed Bubakiem dużego, w pełni naukowego zbioru tekstów gwarowych. Tu również udało mu się znaleźć starych i dobrych informatorów, tak że teksty ze Spiszu są równie dobre jak z Zębu.

Wartość wymienionych wyżej książek Bubaka dla dialektologii i badań nad kulturą Podhala i Spiszu jest ogromna. Poza tym są one nieocenionymi źródłami materiału dla nowo powstającego ogólnopolskiego „Słownika gwar polskich” PAN (SGP PAN 1977-2018).

Profesor Bubak zapisał też teksty gwarowe w wielu innych miejscowościach Polski południowej. Wymienić tu należy następujące wsie: Jankowice (Bubak, 1961a, 1963), Kleszczów (Bubak, 1961b), Kujakowice Dolne (Bubak, 1963), Bukowina Tatrzańska (Bubak, 1965), Zakopane (Bubak, 1991b), Kamienica (Bubak, 1970a), Majscowa, Żółków (Bubak, 1970b).

$\mathrm{Z}$ pięknego wspomnienia, które naszemu uczonemu poświęcił profesor Bogusław Dunaj w „Złotej księdze UJ”, dowiadujemy się, że profesor Bubak przygotowywał od dawna zbiór tekstów gwarowych ze wszystkich wsi Podhala, czego niestety nie zdołał zakończyć (Dunaj, 2000, s. 754).

Opublikowawszy obfite zbiory tekstów przystąpił profesor Bubak do charakterystyki stanu badań i opisu interesujących go gwar. W latach osiemdziesiątych i dziewięćdziesiątych ubiegłego wieku opublikował takie rozprawy, jak: „Stan badań nad gwarami na Spiszu” (Bubak, 1983), „Polskie gwary spiskie” (Bubak, 1987a) i „Gwara Zakopanego” (Bubak, 1991a).

W pierwszej z wymienionych prac dał gruntowny i krytyczny przegląd badań na Spiszu od pierwszego chronologicznie opisu Czambela w roku 1906 (Czambel, 1906) po studia i atlas Sobierajskiego zakończony w latach siedemdziesiątych ubiegłego wieku (Sobierajski, 1966-1977). Dalsze dwie prace są syntetycznymi ujęciami, w których autor musiał się zmierzyć z różnymi dawnymi, nie zawsze trafnymi uogólnieniami swoich poprzedników.

Znaczenie naukowe tych rozpraw jest wielkie. Wielu uczonych przed Bubakiem zajmowało się gwarami Podhala i Spiszu, ale właśnie on zostawił nam ujęcia syntetyczne opierające się na znakomitym zebranym przez siebie materiale i na danych zebranych wcześniej przez innych badaczy.

Osobny rozdział w twórczości dialektologicznej profesora Józefa Bubaka stanowią prace poświęcone stylizacji gwarowej. Wymienić tu należy następujące studia: „Stylizacja gwarowa na przykładzie „Rodu Gąsieniców” J. Kapeniaka” (Bubak, 1977), „Elementy gwary zakopiańskiej w twórczości Jana Kasprowicza” (Bubak, 1997a), „Gwara podhalańska w pisarstwie Stanisława Witkiewicza" (Bubak, 1997b).

Wspomniane studia zajmujące się stylizacją gwarową czyta się z ogromnym zainteresowaniem. Tworząc je miał już autor wielką wiedzę o gwarze podhalańskiej, jaką zdobył przy zbieraniu tekstów z Zębu i pisaniu syntetycznego ujęcia gwary Zakopanego. Gdy się więc czyta dość krytyczną ocenę dzieła Kapeniaka, dostrzega się na każdym kroku fachową, opartą na niezbitych faktach znajomość rzeczy. Wskazać przy tym należy, że autor równie trafnie posługuje się danymi dialektologicznymi, jak metodologią stylizacji językowej, powołując się na autorytety w tej dziedzinie.

W studium „Elementy gwary zakopiańskiej w twórczości Jana Kasprowicza” (Bubak, 1997a) bardzo interesująca jest między innymi polemika z twierdzeniem Konrada Górskiego, który w swojej pracy „Tatry i Podhale w twórczości Jana Kasprowicza”, wydanej w roku 1926, pisze, co następuje: „Góralską gwarą Kasprowicz nie pisze nigdy, ale przejmuje cały szereg słów, których używa, czy to jako wyrazy, już to wciągnięte do skarbca języka literackiego (wierch, turnia, wanta, smrek, perć, juhas, baca, gazda), czy też dla charakterystyki postaci ze świata góralskiego" (Górski, 1926, s. 33). Otóż Bubak wykazał, że Kasprowicz jednak ma w swoim dorobku twórczym tekst pisany gwarą. Jest to utwór mający tytuł „Z Tatr”, pisany wg Bubaka od początku do końca gwarą zakopiańską. Drukowany był w odcinkach w „Kurierze Lwowskim” od 19 sierpnia do 10 września 1898. Tekst ten — jak stwierdza Bubak — nie był przez autora przedrukowany i na wiele lat został zapomniany. Ponownie wydano go dopiero w Wydawnictwie Literackim w roku 1976 (w opraco- 
waniu R. Lotha [Kasprowicz, 1976]). Bubak bardzo dokładnie opisuje cechy gwary w omawianym utworze Kasprowicza i wyraża o nim następującą opinię: „Moim zdaniem „Z Tatr” można potraktować jako jedno z najstarszych źródeł pisanych do wiedzy o gwarze podhalańskiej i na pewno jako utwór literacki najlepiej oddający tę gwarę w XIX wieku." (Bubak, 1997a, s. 55, 61-66). Ponieważ w innych swoich utworach związanych z góralszczyzną Kasprowicz nigdy już nie używał tak konsekwentnie góralskich właściwości gwarowych, Bubak przypuszcza, że ostateczny kształt utworowi „Z Tatr” nadali zakopiańczycy A. Stopka i W. Matlakowski, których Kasprowicz znał i pisał o nich z uznaniem (Bubak, 1997a, s. 67).

Znakomita znajomość gwar górskich pozwoliła też Bubakowi na różne inne prace związane z literaturą piękną. Wymienić tu można opracowanie filologiczne tekstu „Wesela spiskiego" Jana Plucińskiego (Pluciński, 1987) i napisanie komentarza filologicznego do tego dzieła (Bubak, 1987b, s. 139-140), a do baletu „Harnasie” Karola Szymanowskiego danie komentarza językowego (Bubak, 1985, s. XLIX-LII) oraz przygotowanie edytorskie tekstu libretta (Szymanowski, 1985).

Do dialektologicznej działalności Bubaka zaliczyć też należy jego wieloletni udział w „Sabałowych bajaniach", odbywających się regularnie co roku w Bukowinie Tatrzańskiej. W latach 19751998 pełnił na tych artystycznych występach zaszczytną funkcję jurora. Uczestniczył też jako juror w analogicznej, tym razem limanowskiej imprezie, noszącej nazwę „Limanowska słaza””.

Wiedzą dialektologiczną i gruntowną znajomością gwary podhalańskiej posłużył się też Bubak w swojej obfitej twórczości onomastycznej. Jego kompetencja w tym zakresie umożliwiła mu danie trafnych wyjaśnień nazw osobowych i miejscowych w licznych pracach, z których wymieniam tu tylko kilka: „Nazwa Zakopane i nazwy terenowe miasta Zakopanego” (Bubak, 1991c), „Nazwy osobowe mieszkańców Zakopanego (nazwiska, przydomki, przezwiska i imiona)" (Bubak, 1991d), „Nazwiska ludności dawnego starostwa nowotarskiego” (Bubak, 1970c). Jako przykład trafnego zastosowania wiedzy dialektologicznej w interpretacjach onomastycznych można przytoczyć objaśnienie nazwy Zakopane. W podsumowaniu dłuższych wywodów popartych bogatą dokumentacją Bubak konkluduje:

[...] należy stwierdzić, że nazwa Zakopane nie łączy się z appellativum zakopane, lecz pochodzi od wyrażenia przyimkowego Za Kopane, za Kopanem. Ten typ strukturalny nazw znany jest w polskiej toponomastyce, zwłaszcza wśród nazw terenowych. Za pochodzeniem tej nazwy od wyrażenia przyimkowego przemawia też $a$ pochylone w przedrostku $z a-\mathrm{w}$ formach gwarowych [!]. Jest to nazwa topograficzna, określająca położenie danego obiektu względem innego obiektu w terenie (np. pole, wyrobisko leżące za Kopanem) (Bubak, 1991c, s. 497).

W niniejszym artykule nie może wreszcie zabraknąć wzmianki o blisko tysiącu fiszek rękopiśmiennych z gwar cieszyńskich (w tym ok. 400 z Wisły, ok. 200 z Istebnej, ok. 200 z Jaworzynki i ok. 150 z Koniakowa) dostarczonych przez profesora Bubaka do kartoteki ogólnogwarowego „Słownika gwar polskich” PAN (SGP PAN 1977-2018). W kartotece tej są poza tym tysiące relacji wyekscerpowanych z jego drukowanych dzieł dialektologicznych.

Przyglądając się całości twórczości dialektologicznej profesora Bubaka zauważamy, że dotyczy ona przede wszystkim dwu regionów - Podhala i Spiszu. Na początku swej drogi naukowej Bubak nagrywał w terenie, przepisywał $\mathrm{i}$ wydawał drukiem liczne teksty gwarowe $\mathrm{z}$ tego terenu. Z kolei, mając już materiał gwarowy, opracowywał i publikował opisy systemu językowego wymienionych gwar i wypowiadał się w szeregu artykułów na temat stylizacji gwarowej w dziełach literatury pięknej (Witkiewicz, Kasprowicz, Szymanowski, Pluciński, Kapeniak). Należy też podkreślić, że w licznych dziełach onomastycznych Bubaka dotyczących Podhala zauważa się celne wyjaśnienia językoznawcze, ukazujące gruntowną wiedzę dialektologiczną autora.

1 Za informację o tej sferze działalności dialektologicznej profesora Bubaka dziękuję p. doktorowi Arturowi Czesakowi. 
Najogólniej można powiedzieć, że badania dialektologiczne profesora Józefa Bubaka bardzo posunęły naprzód wiedzę o gwarach Podhala i Spiszu oraz tym samym ułatwiły dalsze badania, a on sam stał się głównym autorytetem w zakresie gwary podhalańskiej, chętnie zapraszanym do różnych akcji i wydawnictw związanych z tym regionem.

Profesor Bubak nieraz zaglądał do Zakładu Dialektologii Polskiej Instytutu Języka Polskiego PAN, w którym opracowuje się „Słownik gwar polskich”. Nasze środowisko słownikowe łączyły z nim wspólne zainteresowania badawcze i miłe koleżeńskie stosunki.

Wspominamy też Profesora Bubaka jako znakomitego mówcę przejawiającego swój talent oratorski i piękną polszczyznę na różnych zebraniach naukowych.

$\mathrm{Na}$ zakończenie pragnę wyrazić moje głębokie przekonanie, że całą twórczość lub przynajmniej część dzieł Bubaka powinno się opublikować w wydaniu zbiorowym, w którym należałoby także zamieścić bibliografię jego prac.

\section{LITERATURA}

Bubak, J. (1961a). (współautor: W. Lubaś), Teksty z Jankowic [pow. Rybnik]. W: A. Zaręba (red.). Śląskie teksty gwarowe. Biblioteczka Towarzystwa Miłośników Języka Polskiego, nr 14, Kraków, s. 100-105.

Bubak, J. (1961b). (współautor: W. Lubaś), Teksty z Kleszczowa [pow. Gliwice]. W: A. Zaręba (red.). Śląskie teksty gwarowe. Biblioteczka Towarzystwa Miłośników Języka Polskiego, nr 14, Kraków, s. 111-113.

Bubak, J. (1963). Dwa teksty śląskie. ZNUJ, IX, Prace Językoznawcze, z. 5, s. 373-379 [Jankowice s. 373-375; Kujakowice Dolne s. 376-379].

Bubak, J. (1965). (współautor: M. Karaś). Teksty gwarowe z Bukowiny w powiecie nowotarskim. ZNUJ, CXIV, Prace Językoznawcze, z. 15, s. 257-270.

Bubak, J. (1966). Teksty gwarowe ze wsi Ząb w powiecie nowotarskim. ZNUJ, XCVIII, Prace Językoznawcze, z. 12.

Bubak, J. (1970a). Teksty gwarowe z Kamienicy, pow. Limanowa. Język Polski, L, s. 55-60.

Bubak, J. (1970b). Teksty gwarowe z południowo-wschodniej Małopolski (Majscowa, Żółków, pow. Jasło). ZNUJ, CCXXIX, Prace Językoznawcze, z. 29, s. 219-228.

Bubak, J. (1970c, 1971). Nazwiska ludności dawnego starostwa nowotarskiego. T. I-II, WrocławWarszawa-Kraków-Gdańsk.

Bubak, J. (1972). Spiskie teksty gwarowe z obszaru Polski. ZNUJ, CCLXXVIII, Prace Językoznawcze, z. 36.

Bubak, J. (1977), Stylizacja gwarowa na przykładzie „Rodu Gąsieniców” J. Kapeniaka. ZNUJ, CCCCLVII, Prace Językoznawcze, z. 54, s. 251-260.

Bubak, J. (1978). Gwara Koniakowa, Istebnej, Jaworzynki i Wisły. ZNUJ, CDXCV, Prace Językoznawcze, z. 59, s. 27-38.

Bubak, J. (1983). Stan badań nad gwarami na Spiszu. Język Polski, LXIII, s. 322-334.

Bubak, J. (1985). Komentarz filologiczny do tekstów gwarowych w „Harnasiach”. W: Szymanowski K. (1985) Dzieła, t. 24 „Harnasie, balet góralski w jednym akcie w dwóch odsłonach, op. 55". Komitet Redakcyjny: Józef F. Chomiński, Teresa Chylińska, + Zbigniew Drzewiecki, + Zofia Lissa, Mieczysław Tomaszewski, + Eugenia Umińska. Redaktor edycji: Teresa Chylińska. Redaktor tomu: Barbara Konarska. Konsultacja muzyczno-edytorska: Adam Walaciński. Wstęp: Kazimierz Nowacki. Opracowanie filologiczne tekstów gwarowych: Józef Bubak. Kraków, s. LIX-LXI.

Bubak, J. (1987a). Polskie gwary spiskie. ZNUJ, DCCCXI, Prace Etnograficzne, z. 22, (red.) Z. Biały „Studia spiskie”, I, s. 233-262. 
Bubak, J. (1987b). Komentarz filologiczny. W: Wesele spiskie, podał Jan Pluciński, znawca i miłośnik ziemi spiskiej, opracowała Krystyna Kwaśniewicz (s. 139-140). Kraków: Polskie Wydawnictwo Muzyczne.

Bubak, J. (1991a). Gwara Zakopanego. W: R. Dutkowa (red.). Zakopane, czterysta lat dziejów. T. I (s. 528-546). Kraków: KAW.

Bubak, J. (1991b). Tekst gwarowy z Zakopanego. W: R. Dutkowa (red.). Zakopane, czterysta lat dziejów. T. I (s. 547-550). Kraków: KAW.

Bubak, J. (1991c). Nazwa Zakopane i nazwy terenowe miasta Zakopanego. W: R. Dutkowa (red.). Zakopane, czterysta lat dziejów. T. I (s. 492-503). Kraków: KAW.

Bubak, J. (1991d). Nazwy osobowe mieszkańców Zakopanego (nazwiska, przydomki, przezwiska i imiona) W: R. Dutkowa (red.). Zakopane, czterysta lat dziejów. T. I (s. 504-527). Kraków: KAW.

Bubak, J. (1997a), Elementy gwary zakopiańskiej w twórczości Jana Kasprowicza. W: P. Kuleczka (red.). O Janie Kasprowiczu. W siedemdziesięciolecie zgonu. Studia (s. 53-68). Kraków: Oficyna Podhalańska.

Bubak, J. (1997b), Gwara podhalańska w pisarstwie Stanisława Witkiewicza. W: Z. Moździerz (red.). Stanisław Witkiewicz. Człowiek - artysta - myśliciel. (s. 255-274). Zakopane: TMT.

Czambel, S. (1906). Slovenská reč a jej miesto v rodine slovanských jazykov. Turčiansky Sv. Martin.

Dunaj, B. (2000). Józef Bubak 1934-1999. W: J. Michalik, W. Walecki (red.). Uniwersytet Jagielloński. Złota księga Wydziału Filologicznego (s. 747-754). Kraków: Księgarnia Akademicka.

Górski, K. (1926). Tatry i Podhale w twórczości Jana Kasprowicza. Zakopane: Skład główny w Księgarni L. Zwolińskiego.

Hołub-Pacewiczowa, Z. (1931). Osadnictwo pasterskie i wędrówki w Tatrach i na Podtatrzu. Kraków: PAU.

Karaś, M., Zaręba, A. (1964). Orawskie teksty gwarowe z obszaru Polski. ZNUJ, LXIX, Prace Językoznawcze, z. 6.

Kasprowicz, J. (1976). Z Tatr. Opracowanie i posłowie R. Lotha. Kraków: Wydawnictwo Literackie.

Kąś, J. (2015-2019). Ilustrowany leksykon gwary i kultury podhalańskiej. T. 1-2, Bukowina Tatrzańska-Nowy Sącz: Bukowiańskie Centrum Kultury „Dom Ludowy”, t. 3, Bukowina Tatrzańska: Bukowiańskie Centrum Kultury „Dom Ludowy”, t. 4, Kraków: Wydawnictwo Astraia, t. 5-10, Nowy Sącz: Małopolskie Centrum Kultury „Sokół”.

Pluciński, J. (1987). Wesele spiskie, podał Jan Pluciński, znawca i miłośnik ziemi spiskiej, opracowała Krystyna Kwaśniewicz, opracowanie filologiczne: Józef Bubak. Kraków: Polskie Wydawnictwo Muzyczne.

SGP PAN (1977-2018) - Słownik gwar polskich, red.: M. Karaś ([osobny tom zatytułowany] Źródła oraz t. I), J. Reichan (t. II-IX, z. 2), S. Urbańczyk (t. II-V), J. Okoniowa (t. VI-IX, z. 2), B. Grabka (t. VII-X, z. 1), R. Kucharzyk (t. IX, z. 2 - t. X, z. 1); miejsca wydawania: tom Źródła oraz t. I-III: Wrocław-Warszawa-Kraków 1977-1991, t. IV-X z. 1: Kraków 1992-2018.

Sobierajski, Z. (1966-1977). Atlas polskich gwar spiskich na terenie Polski i Czechosłowacji, t. I-IV, Prace Komisji Językoznawczej Poznańskiego Towarzystwa Przyjaciół Nauk. T. I 4, V $1, \mathrm{~V} 3$.

Szymanowski, K. (1985). Dzieła, t. 24 „Harnasie, balet góralski w jednym akcie w dwóch odsłonach, op. 55”. Komitet Redakcyjny: Józef F. Chomiński, Teresa Chylińska, + Zbigniew Drzewiecki, + Zofia Lissa, Mieczysław Tomaszewski, + Eugenia Umińska. Redaktor edycji: Teresa Chylińska. Redaktor tomu: Barbara Konarska. Konsultacja muzyczno-edytorska: Adam Walaciński. Wstęp: Kazimierz Nowacki. Opracowanie filologiczne tekstów gwarowych: Józef Bubak. Kraków: Polskie Wydawnictwo Muzyczne. 